\title{
Legal Hermeneutics
}





\title{
Legal Hermeneutics \\ HISTORY, THEORY, AND PRACTICE
}

\author{
EDITED BY \\ Gregory Leyh
}


University of California Press

Berkeley and Los Angeles, California

University of California Press, Ltd.

Oxford, England

(C) 1992 by

The Regents of the University of California

\section{Library of Congress Cataloging-in-Publication Data}

Legal hermeneutics : history, theory, and practice / edited by Gregory Leyh.

p. $\mathrm{cm}$.

Roundtable discussion at the 1987 American Political Science

Association meeting in Chicago, III.

Includes bibliographical references and index.

ISBN 0-520-07283-9 (cloth : alk. paper). - ISBN 0-520-07284-7 (paper : alk. paper)

1. Law-Interpretation and construction. I. Leyh, Gregory.

II. American Political Science Association.

K290.L44 1991

$340-\mathrm{dc} 20$

Printed in the United States of America 987654321

The paper used in this publication meets the minimum requirements of American National Standard for Information Sciences-Permanence of Paper for Printed Library Material, ANSI Z39.48-1984. (-) 
For Jan 
